\title{
Growth and yield of lettuce cultivars under organic fertilization and different environments
}

\author{
Alisson Franco Torres da Silva', Rodrigo Cirqueira Avelino', Leonardo Pereira da Silva Brito', \\ João Carlos Rocha dos Anjos', José Valdenor da Silva Júnior', \\ Márkilla Zunete Beckmann-Cavalcante ${ }^{2}$
}

'Federal University of Piauí, Bom Jesus, Brazil

${ }^{2}$ Federal University of São Francisco Valley, Petrolina, Brazi

Corresponding autor, e-mail: markilla.beckmann@univasf.edu.br

\begin{abstract}
Lettuce (Lactuca sativa L.) is a leafy vegetable that could be grown under mineral or organic fertilizing, being also very influenced by environmental conditions. This study evaluated the growth and yield of lettuce cultivars submitted to different doses of organic fertilization and environmental conditions. The experiment was carried out at the Horticulture Sector of the Campus Cinobelina Elvas, at the Federal University of Piauí (CPCE/UFPI), Brazil. The experimental was carried out in a completely randomized block design, with the treatments distributed in split-split-plot, according to cultivation systems in the plots (with $50 \%$ of shading and outdoor cultivation), organic fertilization rates in subplots $\left(0,20,40,60\right.$ and $\left.80 \mathrm{tha}^{-1}\right)$ and lettuce cultivars in the sub-subplots ('Delícia', 'Babá de Verão' and 'Itapuã 401') with three repetitions and with eighteen plants per experimental unity and four useful plants per plot. Plant height, number of leaves, head circumference, stem length, leaf area, leaves chlorophyll content, commercial fresh mass, shoot dry matter and lettuce yield were evaluated. For the conditions in which the present study was carried out, the use of doses of organic fertilization with cattle manure influenced lettuce growth and yield using $50 \%$ of shading and is also suggested the use of the cultivars 'Delícia' and 'Babá de Verão', in a protected environment (50\% of shade).
\end{abstract}

Keywords: cattle manure, leafy, Lactuca sativa L., greenhouse

\section{Introduction}

Lettuce (Lactuca sativa L.) is a leafy vegetable consumed all over the world, and in Brazil it is the most produced, commercialized and consumed (IBGE, 2013), due to ease of acquisition and for being produced all over the year, depending on the region. In addition, it is a crop that allows the adoption of different production systems with different technological levels (Freitas et al., 2016).

Based on this information, in many regions of Brazil, part of the production comes from small farms with little founding to invest in the crop, especially regarding plant fertilization supplements. It is a crop which presents positive responses to organic fertilization. Silva et al. (2010) reported that the use of organic fertilizers has increased due to the beneficial effects that organic matter provides to intensively and conventional cultivated soils. However, the source and ideal dose of organic fertilizer for lettuce cultivation is not yet a consensus in the literature, since the doses can vary according to soil, climate and cultivar conditions used (Silva et al., 2010; Batista et al. 2012; Figueiredo et al., 2012).

Another important aspect associated with lettuce cultivation is the climatic condition, since its adaptation to places of high temperature and luminosity can cause problems in its growth, 
preventing the crop from expressing its full productive potential. When exposed to stress conditions, as in high temperatures, lettuce tends to reduce its cycle, compromising the production and making the leaves more rigid, and also to stimulating the tassel induction, an undesirable characteristic, since it makes the vegetable unfeasible for commercialization (Luz et al., 2009).

Puiatti \& Finger (2005) report that the maximum tolerable temperature for lettuce is around $30^{\circ} \mathrm{C}$, with an optimum variation of 4 to $27^{\circ} \mathrm{C}$. Thus, in regions with temperatures higher than the indicated, the adaptation of cultivars may be difficult. The Bom Jesus region, in the state of Piauí, for example, has a warm and semi-humid climate with an annual average temperature of $26.6^{\circ} \mathrm{C}$, reaching high temperatures all over the year, with maximum temperatures above $36^{\circ} \mathrm{C}$ (Bandeira et al., 2010). According to Queiroz et al. (2014), the challenge for this species is to develop tropicalized genotypes, because it is an originally mild climate species, since it presents high demand in all regions of Brazil.

In this context, the aim of this study was to evaluate the growth and yield of lettuce cultivars under organic fertilization and cultivation environments in Bom Jesus, Piauí State, Brazil.

\section{Material and Methods}

The experiment was conducted in the Horticulture Sector of Campus Cinobelina Elvas at the Federal University of Piauí (CPCE / UFPI), in Bom Jesus, Piauí (0904'28 "S, 4421'31"W, 277 m), Brazil, from September to November 2011 , on soil classified as distrofic yellow Latosol. The soil chemical and granulometric analysis, in the 0-20 cm depth layer, presented the following characteristics: organic matter 2.0\%; $\mathrm{pH}\left(\mathrm{CaCl}_{2}\right)$ 5.9; $\mathrm{Ca}^{2+} 3.5 \mathrm{cmol}_{\mathrm{c}} \mathrm{dm}^{-3} ; \mathrm{Mg}^{2+} 1.1 \mathrm{cmol}_{\mathrm{c}} \mathrm{dm}^{-3} ; \mathrm{Al}^{3+}$ $0.0 \mathrm{cmol}_{\mathrm{c}} \mathrm{dm}^{-3} ; \mathrm{H}^{+}+\mathrm{Al}^{3+} 2.5 \mathrm{cmol}_{\mathrm{C}} \mathrm{dm}^{-3}$; CEC 7.4 $\mathrm{cmol}_{\mathrm{c}} \mathrm{dm}^{-3}$; Base saturation $66.0 \mathrm{cmol}_{\mathrm{c}} \mathrm{dm}^{-3} ; \mathrm{P}$ (Melich) $110.00 \mathrm{mg} \mathrm{dm}^{-3} ; \mathrm{K}^{+} 1.32 \mathrm{mg} \mathrm{dm}^{-3}$; sand $40 \%$; silt $21 \%$ and clay $39 \%$. The characteristics of the cattle manure were: organic matter $20.5 \%$; $\mathrm{N}$ $0.80 \% ; \mathrm{Mg} 0.24 \% ; \mathrm{K}_{2} \mathrm{O} 1.64 \% ; \mathrm{P}_{2} \mathrm{O}_{5} 0.24 \%$ and $\mathrm{Ca}$ $0.62 \%$.

The experiment was carried out in a complete randomized block design, with the treatments distributed in split-split-plot, with cultivation systems in the plots (planted with $50 \%$ of shading and open environment (full sun) cultivation); doses of organic fertilization in the plots $\left(0,20,40,60\right.$ and $\left.80+\mathrm{ha}^{-1}\right)$, and lettuce cultivars in the sub-subplots ('Delícia', 'Babá de Verão' and 'Itapuã 401'), with three replicates and each experimental unit composed by eighteen plants, with evaluation of four useful plants of the plot.

For the production of lettuce seedlings, pelletized seeds were used, with one seed per cell, seeded in trays of expanded polystyrene with capacity of 200 cells, arranged at $0.80 \mathrm{~m}$ above soil surface, on wooden pallets. The substrate for the production of the seedlings was based on regional materials used by small growers, elaborating the mixture based on carnauba straw residue with rice skin and vermiculite in the proportion of $1: 1: 1(\mathrm{v} / \mathrm{v})$. The seedlings were irrigated twice a day using a sprayer.

The transplanting of the seedlings was carried out 20 days after sowing, on 10/17/2011, when the seedlings presented three definitive leaves, at a spacing of $0.30 \times 0.30 \mathrm{~m}$. The area of each environment (cultivation system) had a dimension of $28 \times 4 \mathrm{~m}$ and each site that received the organic fertilization had $1.25 \times 1.25 \mathrm{~m}$. The environment with the shading screen presented $1.70 \mathrm{~m}$ in height. The light protection was realized on all sides of the environment (roof and sides) up to a height of $0.70 \mathrm{~m}$ from soil level.

Planting fertilization was carried out 10 days before transplantation with the incorporation of cattle manure doses into the soil of the respective treatment, corresponding to each dose of organic fertilization. The doses were based on the amount of cattle manure commonly used in the region of Bom Jesus, PI (average of $40 \mathrm{tha}^{-1}$ ). The levels of cattle manure $\left(0,20,40,60\right.$ and $\left.80+\mathrm{ha}^{-1}\right)$, based on the cattle manure analysis, respectively, providing the amounts of $0,16,32,48$ and $64 \mathrm{~kg} \mathrm{ha}^{-1}$ of $\mathrm{N} ; 0 ; 4.8$; 9.6; 14.4 and $19.2 \mathrm{~kg} \mathrm{ha}^{-1}$ of $\mathrm{P}_{2} \mathrm{O}_{5}$; and $0 ; 32,8 ; 65.6$; 98.4 and $131.2 \mathrm{~kg} \mathrm{ha}^{-1}$ of $\mathrm{K}_{2} \mathrm{O}$.

Irrigation was performed with garden hoses (Santeno II®) with lateral nozzles to provide a uniform distribution of water. The plants were irrigated once a day for an average time of two hours. Weed control was manual and no spraying 
with any chemicals to control pests and diseases was required.

The temperature, relative air humidity and luminosity in the environments (open and shading) were daily monitored (Figure 1). The temperature and relative air humidity were obtained through a digital thermo-hygrometer (Model Q401BHT, Quimis $\AA$, Brazil), installed in the central part of the environments, with the sensor arranged at a height of 1,50 m; The luminosity was measured using a digital luxmeter (Model LD-240, Instrutherm $\AA$, Brazil) and precipitation data were collected at the Meteorological Station of INMET (Instituto de Meteorologia) installed $500 \mathrm{~m}$ from the crop.
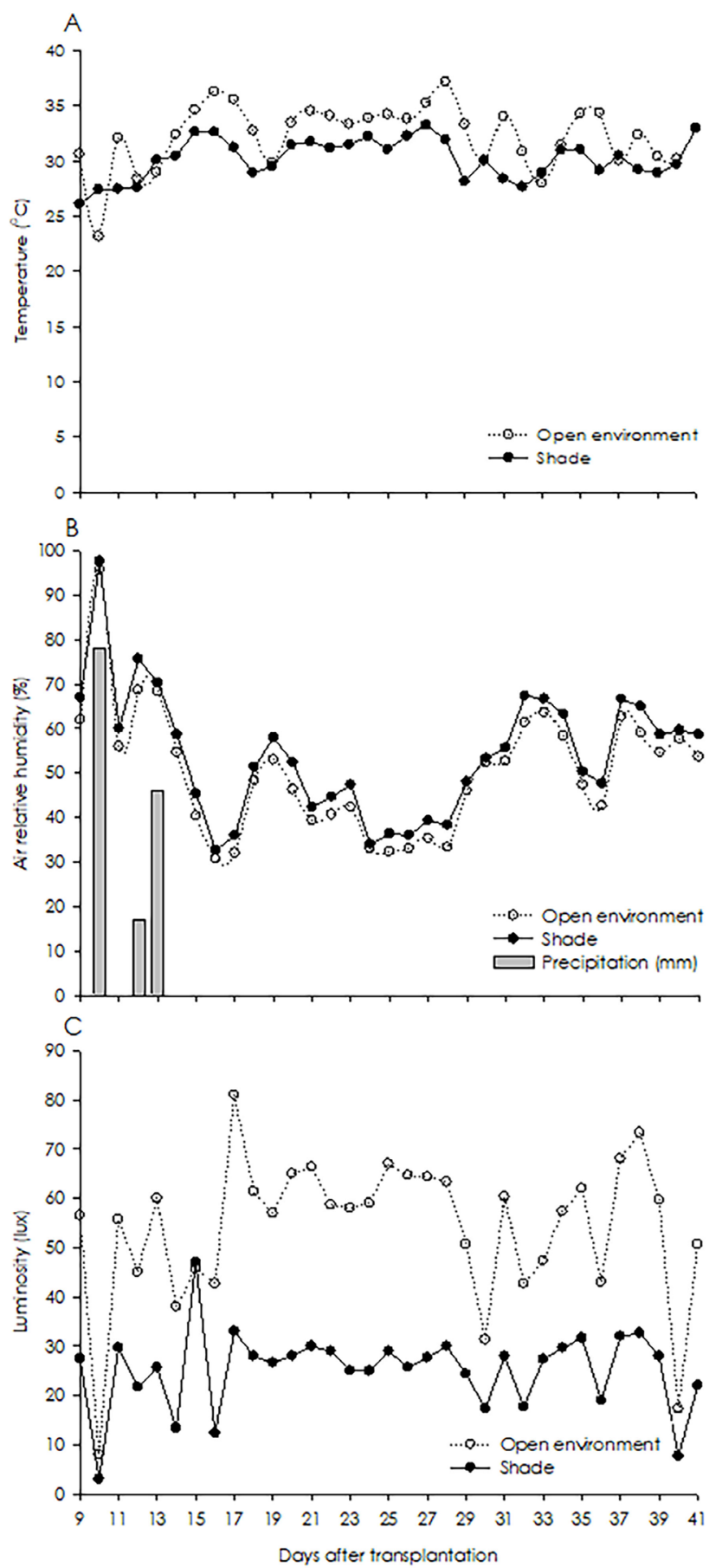

Figure 1. Daily means for air temperature (A), air relative humidity and precipitation (B) and luminosity (C) from the seedlings transplant to lettuce (Lactuca sativa L.) harvest. 
At 41 days after transplantation (DAT), the following variables were evaluated: plant height $(\mathrm{H}, \mathrm{cm})$, measured from the soil level to the highest end of the plant; number of leaves $(\mathrm{NL})$ : not counting yellow and/or dry leaves, starting from the basal leaves to the last open leaf; head circumference ( $\mathrm{HC}, \mathrm{cm})$ : with a tapemeasure around the lettuce head; stem length $(\mathrm{SL}, \mathrm{cm})$ measured from the base to the final insertion of the leaves; leaf area (LA), using areas known as blades, according to Benincasa (2003). Discs were removed and the rest of the material from the leaf of each analyzed plant group were packed separately in paper bags and taken to the forced-air circulation oven at $65^{\circ} \mathrm{C}$, until constant weight. The leaf area was estimated by the equation $A=D a \times(d d m+r b) / d d m$, where $A=$ area of the blades sampled; $D a=$ area of the discs; $d d m$ = discs dry mass; rb= dry mass of the remaining blades; leaf chlorophyll content (LC), expressed as leaf chlorophyll index (LCI) and performed using a digital chlorophyllometer (Model CFL1030, Falker $\AA$, Brazil). Two plants were randomly selected in an useful plot and in each plant, three leaves were chosen to obtain a representative average of each plot, being carried out three readings per leaf (in the base, in the median and at the apex of the leaf); head fresh mass (HFM, g), by weighing, removing the damaged external leaves; head dry mass (HDM, g), the plant material was placed in an oven with forced air circulation at a temperature of $65^{\circ} \mathrm{C}$ until constant weight; and yield ( $\mathrm{Y}, \mathrm{th}^{\mathrm{h}}$ ) obtained from the production of fresh commercial mass of each plant, removing the damaged and/or blemished leaves before weighing, cutting the roots at the height of insertion of the first root. Later the fresh mass obtained by plant was multiplied by the total number of plants in one hectare.

Data were submitted to variance analysis, by $F$ test, for the significant effect confirmation; cultivars and environments of cultivation were compared by Tukey's test and simple correlations between variables were performed using the Assistat software. Organic fertilizers doses were submitted to quantitative analysis using simple regression with the aid of Sigmaplot 12.0.

\section{Results and Discussion}

The number of leaves, head fresh mass and yield were influenced $(P<0.05)$ by cattle manure doses and their interaction with the environment (Table 1). Regarding the interactions, for the number of leaves per plant (Figure 2A) a quadratic and decreased linear effect were observed when plants were conducted in open and shaded environment, respectively. The highest number of leaves (25.32) in 50\% shading environment was observed with the application of $40 \mathrm{t} \mathrm{ha}^{-1}$ of cattle manure, on the other hand, when grown in an open environment, the highest number of leaves $(28,25)$ was observed in plants without application of cattle manure. Quadratic equations were obtained for fresh head mass (Figure 2B) and yield (Figure 2C). The highest yields observed were, $244.26 \mathrm{~g} \mathrm{plant}^{-1}$ and 28.14 $\dagger \mathrm{ha}^{-1}$, respectively, using $80 \mathrm{t} \mathrm{ha}^{-1}$ of organic fertilization for plants under shade environment. In open environment cultivation, the highest yields were obtained at a dose of $40 \mathrm{tha}^{-1}$ and 60 t ha- ${ }^{-1}$, respectively, resulting in a fresh head mass equivalent to $219.64 \mathrm{~g} \mathrm{plant}^{-1}$ and a yield of 25.30 t ha-1.

These results, especially for head fresh mass, are below the values observed by Abreu et al. (2010), which obtained a fresh mass of $91.14 \mathrm{~g}$ when growing lettuce with only $30 \mathrm{t} \mathrm{ha}^{-1}$ of cattle manure. On the other hand, they are superior to the results presented by Peixoto Filho et al. (2013) which, when producing lettuce using cattle manure in the first crop cycle, obtained 15 leaves plant ${ }^{-1}, 102.50 \mathrm{~g} \mathrm{plant}^{-1}$ and $26.72 \mathrm{t} \mathrm{ha}^{-1}$. The same authors evaluated the residual effect of applied cattle manure during the second crop cycle and obtained a maximum yield of $37.59 \dagger$ $\mathrm{ha}^{-1}$.

It is possible the improvement of the values of these variables obtained for the region of the present study applying larger doses of cattle manure or by performing consecutive cycles in the same area to take advantage of the residual effect of the fertilizer, as verified by Peixoto Filho et al. (2013). A fact that can be assigned to the observed results in the present study is the slow mineralization of the organic matter of cattle manure, which can directly interfere in the availability of nutrients for the plants, especially $N$ 
Table 1. Height, number of leaves per plant, head circumference, stem length, leaf area, leaf chlorophyll, head fresh mass, head dry mass and yield of lettuce cultivars as a function of organic fertilization and cultivation environment.

\begin{tabular}{|c|c|c|c|c|c|c|c|c|c|}
\hline \multirow{2}{*}{ Source of variation } & $\mathrm{H}$ & NL & $\mathrm{HC}$ & SL & LA & LC & HFM & HDM & $\mathbf{Y}$ \\
\hline & $-\mathrm{cm}-$ & $-\cdots \cdot$ & $-\mathrm{cm}-$ & $-\mathrm{cm}-$ & $-\mathrm{cm}^{2}-$ & - ICF - & g plant $^{-1}$ & g plant $^{-1}$ & - t ha-1 $^{-1}$ \\
\hline Fertilization (F) ("F") & $1.7^{\mathrm{ns}}$ & $0.2^{\mathrm{ns}}$ & 1.0 & $0.4^{\mathrm{ns}}$ & $0.3^{\text {ns }}$ & $0.7^{\mathrm{ns}}$ & $0.1^{\mathrm{ns}}$ & $0.5^{\mathrm{ns}}$ & $0.1^{\mathrm{ns}}$ \\
\hline C.V. (\%) & 21.9 & 25.5 & 17.8 & 42.7 & 38.2 & 17.6 & 48.9 & 41.8 & 48.9 \\
\hline Environment (En) & $17.9^{* *}$ & $4.9^{* *}$ & $5.7^{*}$ & $2.4^{\text {ns }}$ & $10.6^{* *}$ & $0.9^{\text {ns }}$ & $12.8^{* *}$ & $0.2^{\mathrm{ns}}$ & $12.8^{* *}$ \\
\hline Shade & $17.9 a$ & $24.2 b$ & $49.6 a$ & $6.2 a$ & $279.9 a$ & $28.1 a$ & $222.5 a$ & $5.1 a$ & $25.6 a$ \\
\hline Open environment & $14.6 b$ & $25.6 a$ & $46.9 \mathrm{~b}$ & $5.1 \mathrm{a}$ & $197.4 b$ & $27.4 a$ & $192.6 \mathrm{~b}$ & $4.9 a$ & $22.2 b$ \\
\hline C.V. (\%) & 22.5 & 12.0 & 11.1 & 28.5 & 50.3 & 13.7 & 19.1 & 44.2 & 19.1 \\
\hline Cultivars (C) & $9.1^{* *}$ & $327.9 * *$ & $6.9^{* *}$ & $46.6^{* *}$ & $1.9^{\text {ns }}$ & $21.1^{* *}$ & $2.0^{\text {ns }}$ & $0.9^{\text {ns }}$ & $2.0^{\text {ns }}$ \\
\hline Cl (Delícia) & $14.8 \mathrm{~b}$ & $14.7 \mathrm{c}$ & $48.9 a$ & $3.8 \mathrm{~b}$ & $227.8 a$ & $31.7 a$ & $197.7 a$ & $4.7 a$ & $22.8 a$ \\
\hline C2 (Babá de Verão) & $16.6 a$ & $35.0 a$ & $49.7 a$ & $6.8 a$ & $222.3 a$ & $26.1 \mathrm{~b}$ & $216.8 a$ & $5.1 a$ & $25.0 a$ \\
\hline C3 (Itapuã 401) & $17.4 a$ & $25.1 b$ & $46.3 b$ & $7.0 \mathrm{a}$ & $226.0 a$ & $25.5 b$ & $208.1 a$ & $5.2 a$ & $24.0 a$ \\
\hline C.V. (\%) & 15.0 & 12.4 & 7.8 & 24.1 & 39.1 & 14.8 & 17.7 & 26.7 & 17.7 \\
\hline Interaction F x En & $1.0^{\text {ns }}$ & $3.8^{*}$ & $1.7^{\mathrm{ns}}$ & $1.3^{\text {ns }}$ & $1.0^{\text {ns }}$ & $1.3^{\text {ns }}$ & $4.0^{*}$ & $1.4^{\mathrm{ns}}$ & $4.0^{*}$ \\
\hline Interaction $\mathrm{F} \times \mathrm{C}$ & $0.2^{\text {ns }}$ & $0.4^{\mathrm{s}}$ & $3.4^{* *}$ & $0.3^{\text {ns }}$ & $0.7^{\mathrm{ns}}$ & $0.7^{\mathrm{ns}}$ & $1.3^{\text {ns }}$ & $1.2^{\mathrm{ns}}$ & $1.3^{\text {ns }}$ \\
\hline Interaction En x C & $2.0^{\text {ns }}$ & $4.6^{*}$ & $13.3^{* *}$ & $0.0^{\text {ns }}$ & $0.8^{\text {ns }}$ & $15.2^{* *}$ & $0.1^{\mathrm{ns}}$ & $0.4^{\mathrm{ns}}$ & $0.1^{\mathrm{ns}}$ \\
\hline Interaction $\mathrm{F} \times \mathrm{En} \times \mathrm{C}$ & $0.6^{\text {ns }}$ & $0.3^{\text {ns }}$ & $0.7^{\mathrm{ns}}$ & $0.3^{\text {ns }}$ & $0.5^{\mathrm{ns}}$ & $0.5^{\mathrm{ns}}$ & $0.8^{\text {ns }}$ & $0.4^{\mathrm{ns}}$ & $0.8^{\text {ns }}$ \\
\hline
\end{tabular}

for those crops that present short cycle, such as lettuce, as observed by Peixoto Filho et al. (2013).

However, lettuce plants cultivated under fertilization with different doses of cattle manure responded better when grown in a shaded environment (Figure 2), which means that the difference between the cultivation environments was influenced by climatic condition. Probably the use of the shading environment allowed constancy in the temperature and humidity of the soil and, on the other hand, in the condition of open environment, without shading, a greater variation was observed on these two climatic variables. It should be emphasized that the soil cover could not be carried out. This procedure has a direct effect on soil microclimate, promoting a greater evaporation in field condition and could influence, in consequence, the reduction of soil moisture.

According to Wienhold (2007), one factor that interfere in the mineralization of organic matter is the temperature, which can be slower or faster, being the differences mainly attributed to the temperature fluctuation and soil moisture. To confirm this, Kuhnen (2013) concluded that the fraction of cattle manure mineralization, determined in the field, was lower than that obtained with incubation in the laboratory. Only $4.2 \%$ of the $\mathrm{N}$ applied as cattle manure was mineralized in 112 days of incubation in the field, while in the laboratory it was $18.9 \%$, with temperature being one of the factors associated with this result.

The average temperature reached in the crops with or without shade was respectively, was $29^{\circ} \mathrm{C}$ and $32^{\circ} \mathrm{C}$ (Figure 1). In addition, the luminosity was also higher in the open environment, resulting in direct solar radiation incidence on the plants. This situation probably influenced the production variables, since they may be responsible for plants physiological and morphological changes. In addition, it was observed that during the experimental period, in plants of open environment, maximum temperatures of $37^{\circ} \mathrm{C}$ were recorded, which are considered unappropriated for lettuce cultivation, which tolerates the maximum of $30^{\circ} \mathrm{C}$ (Puiatti \& Finger 2005), being a consequence the impediment of the productive potential of the crop. This predicted result was confirmed, which means that the shade can provide a reduction of light intensity and consequently a temperature decrease, influencing production gains and yield, in agreement with the observations of Santos et al. (2010) and Diamante et al. (2013). This demonstrates the viability of cultivation in hot and semi-moist climate conditions.

Head circumference ( $\mathrm{HC})$ was influenced $(P<0.01)$ by cattle manure doses and their interaction with cultivars (Table 1). It can be 


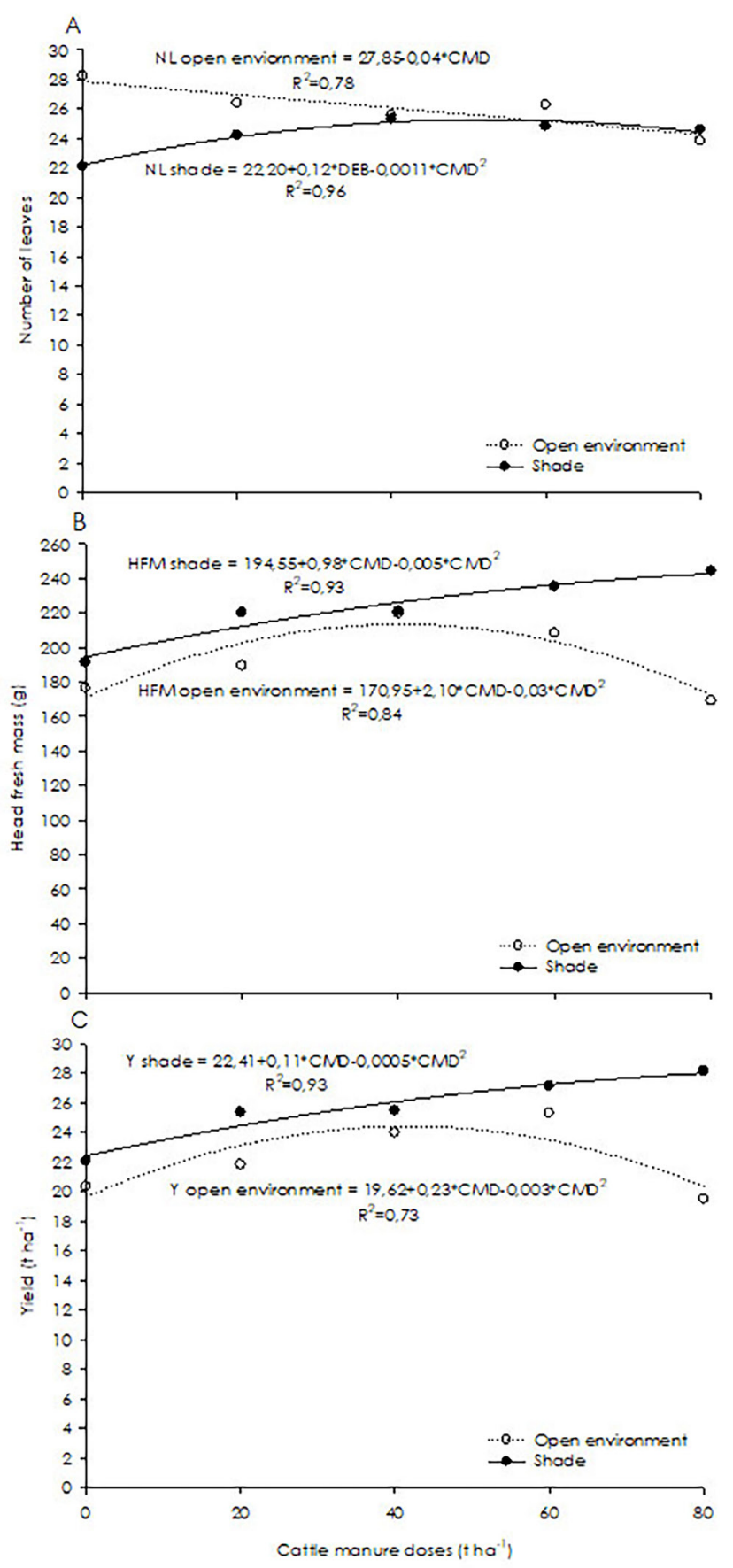

Figure 2. Effect of the interaction of different cattle manure doses and grown environments on number of leaves (A), head fresh mass (B) and yield (c) of lettuce (Lactuca sativa L.).

observed in the interaction that the means were adjusted to the quadratic regression models (Figure 3). The highest head circumference for 'Delícia' $(56.36 \mathrm{~cm})$, 'Babá de Verão' $(52.62 \mathrm{~cm})$ and 'Itapuã 401 ' $(48.95 \mathrm{~cm})$ were obtained at the estimated doses of $30.4+\mathrm{ha}^{-1}, 53.41 \mathrm{tha}^{-1}$ and $60 \mathrm{tha}^{-1}$, respectively, allowing an increase of $13.81 \%, 20.27 \%$ and $15.06 \%$, when compared to no application treatment (dose 0) for the respective cultivars.

Batista et al. (2012) when applying cattle manure in the amount of $200 \mathrm{tha}^{-1}$ obtained a mean head diameter of $26.73 \mathrm{~cm}$ (equivalent to a circumference of $83.97 \mathrm{~cm}$ ), considered above those found in the present study. It is known that fertilization is a fundamental management so that crops can express their productive potential, and that organic fertilization, also confirmed by Silva 
et al. (2011) not only increases the lettuce yield, but also produces plants with better qualitative characteristics than those grown exclusively with mineral fertilizers, also influencing their nutritional quality.

Considering the hypothesis that the decomposition and mineralization of the organic residue did not occur in a timely manner so that the culture could use the nutrients more efficiently, which is very important (Figueiredo et al., 2012), and that the soil condition was the same for the three cultivars under study, it is suggested that this difference is attributed to the genetic material used. Nevertheless, they did not present the minimum commercial diameters reported in the packages that is around 20-30 $\mathrm{cm}$. Possibly, local climatic conditions influenced this variable.

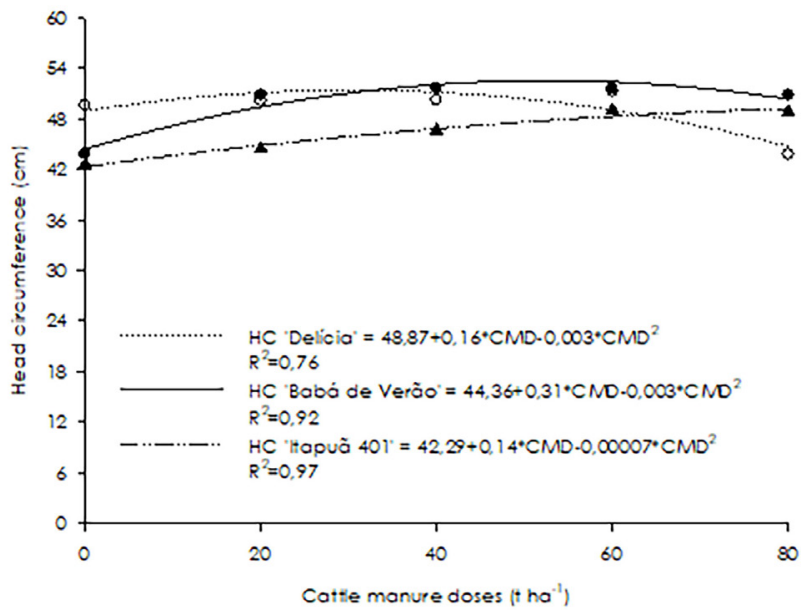

Figure 3. Effect of the interaction of different cattle manure doses and cultivars ('Delícia', 'Babá de Verão' and 'Itapuã 401') for the head circumference of lettuce plants (Lactuca sativa L.).

The interaction of environment $(x)$ cultivars (Table 1) was significant for number of leaves ( $P<0.05)$, head circumference and leaf chlorophyll $(P<0.01)$. For the number of leaves (Table 2), it was observed that only the cultivar 'Babá de Verão' was significantly influenced by the cultivation environment, presenting superiority for plants from the cultivation without shading (37.13 leaves plant $^{-1}$ ). Also for this variable, among the cultivars, a significant influence of the cultivation environments was observed, following a trend, in which the cultivar 'Babá de Verão'> 'Itapuã 401'> 'Delícia'.

Results obtained by Santos et al. (2009), evaluating looseleaf lettuce cultivars were 9.7 to 20.4 leaves plant ${ }^{-1}$, indicating that this characteristic can be influenced by the local of cultivation, as well as the genetic component.

Certainly, the temperature of the air together to the genetic material influenced the observed results. According to Hermes et al. (2001), lettuce needs 45.1 degrees-day for the emission of a new leaf, suggesting that a greater accumulation of degrees-day increases the number of leaves. In addition, it can also accelerate the process of leaf appearance which may consequently reduce the crop cycle. According to Sediyama et al. (2009) the leaf number characteristic is of great interest for a good production, and very high temperatures can accelerate the vegetative phase of the plant causing the early tasseling and reducing the number of leaves. Thus, it is necessary to obtain cultivars with good adaptability and stability to ensure good production.

For the head circumference (Table 2), it can be observed that among the cultivation environments, the use of shade resulted in statistical superiority for both 'Delícia' (52.05 $\mathrm{cm}$ ) and 'Babá de Verão' cultivars $(52,13 \mathrm{~cm})$. In the environment under cover, there was no significant statistical difference between 'Delícia' and 'Babá de Verão', being superior to 'Itapuã 401'; In the open environment, no statistical difference between cultivars was observed.

These results are similar to those found by Prela-Pantano et al. (2015) when evaluating cultivars in open environment at 42 days after 
transplant, in which was observed for 'Bruna' (from the looseleaf group), 'Maravilha' and 'Verdinha' (smooth group) and 'Angelina' (american group) head diameters of $16.38 \mathrm{~cm}, 20.38 \mathrm{~cm}, 17.25 \mathrm{~cm}$ and $15.25 \mathrm{~cm}$. On the other hand, Diamante et al. (2013) obtained larger diameters for 'Elisa', 'Elizabeth', 'Regiane' and 'Regina' cultivars, all from the smooth group with $32.49 \mathrm{~cm}, 28.48 \mathrm{~cm}$, $29.26 \mathrm{~cm}$ and $32.24 \mathrm{~cm}$, respectively. As already mentioned, the explanation for these variations is due to the genetic characteristics of each cultivar as well as the cultivation environment itself.

Table 2. Effect of the interaction of the different environments of cultivation and cultivars for the number of leaves, head circumference and leaf chlorophyll of lettuce plants (Lactuca sativa L.).

\begin{tabular}{ccccc}
\hline \multirow{2}{*}{ Evaluated Variables } & \multirow{2}{*}{ Environments } & \multicolumn{3}{c}{ Cultivars } \\
\cline { 3 - 5 } & & C1 (Delícia) & C2 (Babá de Verão) & C3 (Itapuã 401) \\
\hline \multirow{2}{*}{ Number of leaves } & Shade & $14.76 \mathrm{aC}$ & $32.94 \mathrm{bA}$ & $24.97 \mathrm{aB}$ \\
Head circumference $(\mathrm{cm})$ & Open environment & $14.57 \mathrm{aC}$ & $37.13 \mathrm{aA}$ & $25.17 \mathrm{aB}$ \\
Leaf cholophyll (LC) & Shade & $52.05 \mathrm{aA}$ & $52.13 \mathrm{aA}$ & $44.75 \mathrm{aB}$ \\
& Open environment & $33.65 \mathrm{aA}$ & $26.59 \mathrm{aB}$ & $21.81 \mathrm{bC}$ \\
\hline Means of three repetitions. Means followed by the same lowercase letter in the column are not different between the studied environments for each lettuce cultivar. Means
\end{tabular}

followed by the same uppercase in the line are not different between cultivars for each environment, according to Tukey's test at $P<0.01$ and $P<0.05$.

For leaf chlorophyll, the effect of the interaction of environment ( $x$ ) cultivars (Table 2), resulted in a significantly higher mean for 'Delícia' presented in the open environment $(33.64 \mathrm{LCl})$ than that observed with shading (29.71 LCI); with the opposite effect for the "Itapuã 401" cultivar. Among cultivars, 'Delícia' obtained significantly higher average than the others under both environments, but similar to the 'Itapuã 401' under shade.

Alencar et al. (2012), studying the cultivar 'Elba' (looseleaf group), for example, obtained the lowest reading in the order of $221 \mathrm{LCl}$, when cultivated only using base mineral fertilization in a protected environment. It can be inferred that the climatic condition of the place exerted a strong influence on these results. According to Wahid et al. (2007) high solar radiation, associated with high temperature, can result in degradation of chlorophyll pigments, reduction of carbohydrate photoassimilation and increase of plant respiration. Consequently, it can decrease growth and dry mass accumulation, affecting plant performance.

Analyzing the factors in isolation, it was observed that the growing environment had a significant influence on the height $(17.89 \mathrm{~cm})$ and leaf area $(279.92 \mathrm{~cm} 2)$ of the lettuce plants (Table 1). Santana et al. (2009) presented similar results for 'Quatro Estações' lettuce cultivar with a height of $13.49 \mathrm{~cm}$ (open environment) and $18.89 \mathrm{~cm}(50 \%$ of shade). According to Kendrick \& Frankland (1981), plants kept in shading conditions tend to be taller and have a larger leaf area than those growing in full sunlight. In this condition, intense light tends to favor the development of long palisade cells, often arranged in two or three layers, while shading favors the production of higher amounts of lacunar parenchyma, which is due to the presence of a well development system of spaces, enabling gas exchanges between the internal and external environment. Considering these aspects, the use of shading in high temperature conditions can generate a microclimate, which is more appropriate for the development and growth of lettuce plants, resulting in a better agronomic performance of the crop.

When considering the number of leaves, head circumference and leaf chlorophyll (Table 2 ), it is notorious that, being the same species, there are variations among cultivars due to the genetic characteristics of each material. However, comparing environments, even though a statistically similar number of leaves occur, the largest head size for circumference is obtained when the plants are grown under shading. This fact may be related to the size of leaves within each cultivar, that is, a larger leaf area (Table 1) may result in a larger head circumference.

Regarding the cultivars, when analyzed separately, there was a significant difference for 
the height and stem length variables (Table 1). It was observed that 'Itapuã 401' and 'Babá de Verão' were statistically equal and superior to 'Delícia' for both variables. The 'Delícia' presented $3.84 \mathrm{~cm}$, an acceptable value for the industry, while the cultivars 'Babá de Verão' and 'Itapuã 401', presented respectively 6.80 and $6.99 \mathrm{~cm}$. According to Santana et al. (2012), stems up to $7.0 \mathrm{~cm}$ would be the most suitable for lettuce, but up to $9.0 \mathrm{~cm}$ are less recommended, but the stem is discarded at the time of processing.

Due to the high temperatures during the execution of the experiment, it could be affirmed that the cultivars 'Babá de Verão' and 'Itapuã 401 ' would be stimulated to early tasseling, but it was not observed. According to Luz et al. (2009) stem length is considered a parameter to verify the resistance to early tasseling. The stem elongation may influence the number of leaves, head size, harvest of smaller plants and reduced fresh mass. Therefore, the maximum genetic potential of the cultivars was not expressed, mainly due to climatic conditions. In this sense, together with the choice of the adequate genotype for high temperatures, the use of shading is an alternative that can provide a favorable microclimate for the development of the lettuce crop, promoting gains in production and improving the vegetable quality.

\section{Conclusions}

1. There is an increase in growth and yield with the application of cattle manure doses under shade environment, however, further studies with higher doses are suggested for the Bom Jesus, Piauí, Brazil region;

2. The use of the shading (50\%) can positively affect the growth of lettuce plants, obtaining higher yields;

3. For cultivation in the region of Bom Jesus, Piauí, the cultivation 'Delícia' and 'Babá de Verão' with $50 \%$ of shading are suggested.

\section{References}

Abreu, I.M.O. 2010. Qualidade microbiológica e produtividade de alface sob adubação química e orgânica. Ciência e Tecnologia de Alimentos 30: 108-118.

Alencar, T.A.S., Tavares, A.T., Chaves, P.P.N., Ferreira, T.A., Nascimento, I.R. 2012. Efeito de intervalos de aplicação de urina bovina na produção de alface em cultivo protegido. Revista Verde de Agroecologia 7: 53-67.

Bandeira, E.G., Alves, C.M.D., Melo, L.F.S. 2010. Análise temporal por imagens landsat da expansão da fronteira agrícola no município Bom Jesus-PI. In: III Simpósio Brasileiro de Ciências Geodésicas e Tecnologias da Geoinformação. Anais... Recife-PE, p.1-6.

Batista, M.A.V., Vieira, L.A., Souza, J.P., Freitas, J.D.B.de, Bezerra Neto, F. 2012. Efeito de diferentes fontes de adubação sobre a produção de Alface no município de Iguatu-CE. Revista Caatinga 25: 8-11.

Benincasa, M.M.P. 2003. Análise de crescimento de plantas (noções básicas). Funep, Jaboticabal, Brasil. $41 \mathrm{p}$.

Diamante, M.S., Seabra Júnior, S., Inagaki, A.M., Silva, M.B. da, Dallacort, R. 2013. Produção e resistência ao pendoamento de alfaces tipo lisa cultivadas sob diferentes ambientes. Revista Ciência Agronômica 44: 133-140.

Figueiredo, C.C., Ramos, M.L.G., McManus, C.M., Menezes, A.M. de. 2012. Mineralização de esterco de ovinos e sua influência na produção de alface. Horticultura Brasileira 30: 175-179.

Freitas, A.R., Lopes, J.C., Mengarda, L.H.G., Zanotti, R.F., Venancio, L.P. Allelopathic effect of Passiflora alata Curtis extracts on seed germination. Comunicata Scientiae 7(1): 129132, 2016.

Hermes, C.C., Medeiros, S.L.P., Manfron, P.A., Caron, B., Pommer, S.F., Bianchi, C. 2001. Emissão de folhas de alface em função de soma térmica. Revista Brasileira de Agrometeorologia 9: 269275.

IBGE. Instituto Brasileiro de Geografia e Estatística. Sistema IBGE de recuperação automática (SIDRA). Censo Agropecuário 2006. http://www. sidra.ibge.gov.br <Acesso em 28 Jan. 2013>

Kendrick, R.E., Frankland, B. 1981. Fitocromo e crescimento vegetal. Editora USP, São Paulo, Brasil. 76 p.

Kuhnen, F. 2013. Mineralização de nitrogênio de solos e de resíduo orgânico em laboratório e em campo. 64f. (Tese de Doutorado) - Universidade Estadual Paulista, Jaboticabal, Brasil.

Luz, A.O., Seabra Júnior, S., Souza, S.B.S de, Nascimento, A.S. 2009. Resistência ao pendoamento de genótipos de alface em ambientes de cultivo. Agrarian 2: 71-82.

Peixoto Filho, J.U., Freire, M.B.G. dos S., Freire, F.J., Miranda, M.F.A. 2013. Produtividade de 
alface com doses de esterco de frango, bovino e ovino em cultivos sucessivos. Revista Brasileira de Engenharia Agrícola e Ambiental 17: 419-424.

Prela-Pantano, A., Novo, M.C.S.S., Trani, P.E. 2015. Desempenho de cultivares de alface na região de Americana, SP. Irriga 20: 92-104.

Puiatti, M., Finger, F.L. 2005. Fatores climáticos. In: Fontes, P.C.R. (ed.) Olericultura teoria e prática. Suprema, Rio Branco, Brasil. p. 17-38.

Queiroz, J.P.S., Costa, A.J.M. da, Neves, L.G., Seabra Júnior, S., Barelli, M.A.A. 2014. Estabilidade fenotípica de alfaces em diferentes épocas e ambientes de cultivo. Revista Ciência Agronômica 45: 276-283.

Santana, C.T.C. de, Santi, A., Dallacort, R., Santos, M.L., Menezes, C.B. 2012. Desempenho de cultivares de alface americana em resposta a diferentes doses de torta de filtro. Revista Ciência Agronômica 43: 22-29.

Santana, C.V.S., Almeida, A.C., Turco, S.H.N. 2009. Produção de alface roxa em ambientes sombreados na região do Submédio São Francisco-Ba. Revista Verde de Agroecologia 4: 01-06.

Santos, C.L., Seabra Júnior, S., Lalla, J.G. DE, Theodoro, V.C. de, Nespoli, A. 2009. Desempenho de cultivares de alface tipo crespa sob altas temperaturas em Cáceres - MT. Agrarian 2: 87-98.

Santos, L.L., Seabra Junior, S., Nunes, M.C.M. 2010. Luminosidade, temperatura do ar e do solo em ambientes de cultivo protegido. Revista de Ciências Agro-Ambientais 8: 83-93.

Sediyama, M.A.N., Pedrosa, M.W., Salgado, L.T., Pereira, P.C. 2009. Desempenho de cultivares de alface para cultivo hidropônico no verão e no inverno. Científica 37: 98-106.

Silva, E.M.N.C.P., Ferreira, R.L.F., Neto, S.E. de A., Tavella, L.B., Solino, A.J.S. 2011. Qualidade de alface crespa cultivada em sistema orgânico, convencional e hidropônico. Horticultura Brasileira 29: 242-245.

Silva, F.A.M., Villas Bôas, R.L., Silva, R.B. 2010. Resposta da alface à adubação nitrogenada com diferentes compostos orgânicos em dois ciclos sucessivos. Acta Scientiarum. Agronomy 32: 131-137.

Wahid, A., Gelani, S., Ashraf, M., Foolad, M.R. 2007. Heat tolerance in plants: An overview. Environmental and Experimental Botany 61: 199223.

Wienhold, B.J. 2007. Comparison of laboratory methods and in situ method for estimating nitrogen mineralization in an irrigated silt-loam soil. Communications in Soil Science and Plant Analysis 38: 1721-1732. 